\title{
Enlightenments of TPP for the Intellectual Property Rights Education of Our Country
}

\author{
Xiao-Yan Xue, Guang-Min Li \\ Qingdao University, Qingdao, 266071, China \\ E-mail: 2902342304@qq.com, qdyjsh@163.com
}

\begin{abstract}
With the increasing of intellectual property rights disputes in international trade, intellectual property rights education has become one of the main education programs all over the world. Trans-Pacific Partnership Agreement is one of the most important international multilateral economic negotiation organizations, in which intellectual property right plays an important role in order to reduce the intellectual property rights disputes in the international trade. This paper described intellectual property clause and its characteristics based on the intellectual property related content in TPP; introduced intellectual property rights protection policy in TPP; put forward several enlightenments and advices to the intellectual property rights education of our country according to the above contents and the plight of intellectual property of China.
\end{abstract}

Key words- Intellectual property rights; education; TPP; Enlightenments

\section{INTRODUCTION}

With the increasing of intellectual property rights disputes in international trade, intellectual property rights education has become one of the main education programs all over the world. Primary education stage is critical period to develop education. Intellectual property rights education in primary and secondary schools plays an indispensable basic role for the cultivation of intellectual property right values and innovation consciousness. State Intellectual Property Office (SIPO) and Ministry of Education (ME) recently jointly issued the national primary and secondary school education of intellectual property rights pilot demonstration work plan, which will further cultivate primary and middle school students' spirit of innovation and intellectual property rights consciousness, beyond that provide basic support for innovative talents cultivation. Trans-Pacific Partnership (TPP) Agreement is one of the most important international multilateral economic negotiation organizations, which was formerly known as Trans-Pacific Strategic Economic Partnership Agreement (P4), intends to promote trade liberalization in the Asia-pacific region. In order to prevent members states' intellectual property or some industries interests may be impacted by other countries, the tenth chapter of TPP is intellectual property right, including the definition and principle of intellectual property rights, plays an important role to reduce the intellectual property rights disputes in the international trade. This chapter furthermore provides a lot of enlightenments for intellectual property rights education around the world. This paper analyzed intellectual property clauses of TPP in detail and put forward several enlightenments and advices to the intellectual property rights education of our country.

\section{BACKGROUND OF TPP}

During the 10th APEC informal leaders meeting in October 2002, Singapore, New Zealand and Chile established a free-trade agreement, which Brunei also joined in April 2005. Above-mentioned four countries eventually signed "Trans-Pacific Strategic Economic Partnership Agreement" in May 2005, which is abbreviated "P4 agreement". The agreement calls for contracting parties provide preferential commitment to each other in the field of goods trade, services trade, intellectual property rights, investment and finance, and carry out positive economic and trade cooperation. Because of "P4 Agreement" adopts open attitude, the United States had announced to join the agreement negotiation in 2008, and put forward that "Trans-Pacific Strategic Economic Partnership" was extended to "Trans-Pacific Partnership Agreement" in November 2009, which is abbreviated the "TPP Agreement". The original "P4 agreement" turned into "TPP agreement" nowadays. As a result, Australia, Peru, Japan, Mexico, Canada, Malaysia, Vietnam and other countries all announced to join this agreement negotiation. The above-mentioned countries had held 20 rounds TPP negotiation by the end of the February 2014, and issued "Trans-Pacific Partnership Agreement Outline" in November 2010. The United States has made full use of the existing "P4 agreement" since it joined TPP agreement negotiation, actively promoted various issues and comprehensively dominated this negotiation.

\section{INTELLECTUAL PROPERTY RIGHTS CLAUSES OF TPP}

The 10th chapter of TPP agreement (P4 agreement) is intellectual property rights, a total of seven articles, including the definition and principle of intellectual property rights, general provisions, trademarks, geographical indications, country names, cooperation[1,2]. Article 1 is definition; it confirms the type of protection of intellectual property rights according to the 1 to 7 section of part 2 in the TRIPs agreement in this chapter. Article 2 is the principle of intellectual property rights. It firstly emphasizes the contracting parties have recognized the important role of intellectual property rights in promoting economic and social 
development. Secondly, it requires the contracting parties make efforts to maintain the balance of the interest between obligees and public. At the last, the obligations and responsibilities are stipulated for contracting parties in order to achieve the above principles. Article 3 is the general provision. The terms clearly require contents of this chapter can not interfere with obligations and rights of the TRIPS agreement and the other multilateral agreements; meanwhile it cannot interfere with the contracting parties to adopt the appropriate measures in order to prevent the abuse of intellectual property rights. Contracting parties are also required to protect adjacent rights according to World Intellectual Property Organization Copyright Convention, WIPO Performances and Phonograms Treaty (WPPT) and Berne Convention. Article 4 is trademark, mainly about the opposition to the trademark application and revocation application right of registered trademark, which also demands contracting parties classify the goods and services based on Nice Agreement. Article 5 is geographical indication, it approves the geographical indications of wine and spirits of relevant contracting parties in the form of the attachment, at the same time it appoints contracting parties can decide to delete or add geographical indications in the form of negotiation. Article 6 is country name, this article is relative short, mainly requires contracting parties to ban misleading commercial use of country names on the source of goods. Article 7 is the cooperation between contracting parties. It requires contracting parties to exchange their respective laws and policy informations regularly and sets up the focal points to strengthen the joint law enforcement, promotes the cooperation and communication of law enforcement agencies and education institutions, develops policy dialogues on multilateral occasions, etc.

By study on TPP agreement in this stage, the intellectual property rights section of this agreement actually is the pattern of " Enhanced cooperation and soft clause": (1) TRIPS agreement and international agreements are the benchmark as a whole; (2) Cooperative communication, information exchange and consultation dialogue are attached great importance; (3) There remains a serious lack of substantive provisions and law enforcement rules. To sum up, TPP agreement is a free trade agreement of high liberalization degree. But from the viewpoint of protected pattern of intellectual property rights, this kind of pattern of "Enhanced cooperation and soft clause" seems not live up to its self-positioning. After all, TPP agreement is to be a "comprehensive and high-level free trade agreement facing the 21 st century", but this kind of "soft" text cannot adapt to the demands of TPP development in the future. Such being the case, after the United States dominated TPP agreement negotiations, this kind of the differences of intellectual property rights protection offers huge space and great opportunity for greatly increasing protection clause and improving the level of protection of the United State of TPP agreement negotiations in the future.

\section{INTELLECTUAL PROPERTY RIGHTS PROTECTION POLICY OF TPP}

"Trans-Pacific Partnership Agreement Outline" released in November 2010 describes the intellectual property protection policy as this: "The countries attending TPP agreement negotiation agreed to strengthen and develop the various rights and obligations of TRIPS agreement passed by the world trade organization, which ensures all negotiators can effectively solve the intellectual property rights problems. Now the forms of intellectual property rights are various, such as trademarks, regional marks, copyright and related rights, patents, trade secrets, some necessary data of limited products, the original resources and traditional knowledge. At the same time, all countries attending TPP agreement negotiations agreed to indicate they will work together to maintain the TRIPs agreement and Doha Declaration in relevant law text "[3].

The draft content of intellectual property rights of Trans-Pacific Partnership Agreement formulated by United States was appeared in related website on March 11, 2011[4]. It provides powerful argument information for studying the new development trend of intellectual property rights clause of TPP. The draft law includes: general provisions, trademarks and geographical indications, internet domain names, copyrights, neighboring rights, encrypted satellite and cable signal programs, patent rights, supervision measures of related products (agricultural chemicals), general law enforcement obligation of intellectual property rights, law enforcement practice of relevant intellectual property rights, civil and administrative judicial proceedings and remedial measures, provisional measures, special requirements about border measures, criminal law enforcements, special measures of the digital environment law enforcement, a total of 16 articles and 109 clauses. The content of draft combines many international agreements of intellectual property rights and "best practices" about national intellectual property rights protection, stipulates management and law enforcement about intellectual property rights object in detail.

\section{REVELATION FOR THE INTELLECTUAL PROPERTY RIGHTS EDUCATION OF OUR COUNTRY OF TPP}

The intellectual property rights terms of TPP play an important role in reducing intellectual property rights disputes in international trade. Research on the content of intellectual property rights education of TPP will also provide a lot of enlightenments for intellectual property rights education of our country.

First of all, there remains a big gap between the level of intellectual property rights of our country and the standard of TPP. Under the background that United States will build TPP as "The free trade zone model" of new century. The influence in the field of intellectual property rights is not only confined in its member states, but also will be expanded as the common application standards of all member states in overseas trades. As one of the most important trade partners of The United States, our country is inevitably influenced by TPP intellectual property rights agreement whether we will join in this agreement or not.

Secondly, With the expansion of TPP members states and the ongoing of negotiation process, the influence of the 
new strategy dominated by The United States to Asia-Pacific Economic Integration process has also been gradually expanded[5,6]. Many countries have been absorbed to join the negotiations in the process of development of TPP apart from China. The intention that the United States wants to counterbalance China by TPP is very clear. Therefore the advance of this agreement plays very important impact for China in the Asia-pacific region.

The influence of TPP for China mainly reflects in: (1) Economy aspects. Once TPP gets across the substantial agreement, customs union will form a giant trade discrimination and trade diversion effect in China. At the same time intellectual property rights protection clause of TPP forms trade barriers of intellectual property rights by enhancing international protection standard of intellectual property rights, increases the risk of intellectual property rights infringement, so it will inflict heavy losses on the manufacturing export of China. The increase of compensation quota and strict principle of damage compensation is no doubt a big blow for the suspected infringing enterprises of our country. (2) Political aspects. The purpose of the United States returning to the Asia-Pacific region in the way of TPP is to strengthen the contact with East Asian countries, disperse the concentration ratio of the East Asian regional economic integration, increase the integration difficulty of the East Asian economy and political development, and limit the constructive role of China in regional affairs. Through forum affair transfer, the United States challenges the voice in the international intellectual property rights rules of China, meanwhile avoids the relevant procedure of the multilateral system. It also aggravates the overlap and competition between the international systems in the aspects of international intellectual property rights law enforcement norms and dispute settlement, which will only cause new pressure and threats for our country. (3) Social aspects. The extension of the copyright protection deadline of TPP intellectual property rights clause will bring heavy society burden for member states, force every member state to pay higher royalties, aggravate the North-South imbalance phenomenon of intellectual property rights interests. At the same time it also results in the imbalance of private interests and public interests in drug patent protection. China is the largest generics country all over the world, generic drug industry of our country will face bottleneck dilemma of development because of paying an enormous sum of drug patent licensing royalties if we strengthen the drug patent protection according to the United States requirements.

\section{CONCLUSION}

TPP is an economy and trade agreement covering extensive contents in high standard and high open degree. High requirements were made to its member states, so our country should face the future development trend of TPP with cautious attitude, get refined internally and externally, maintain their own interests and consolidate the dominant position in Asia Pacific region.

This paper interpreted related contents of TPP intellectual property rights in detail. TPP intellectual property rights clause and its characteristics were described; the protection policy and the United States TPP draft content of intellectual property rights in TPP were introduced; several enlightenments and advices for the TPP intellectual property rights education to our country were put forward according to above contents. These contents will provide important guiding significance for the safety education of intellectual property rights in our country and dealing with international intellectual property disputes.

\section{REFERENCES}

[1] W. Liu, J.W. Shen, "Trans-Pacific Partnership Agreement (TPP): research front and architecture", Contemporary Asia Pacific, 2012.

[2] Y.F. Chen, "An analysis of the influence of protection of intellectual property rights on China's foreign trade", Advances in Social and Behavioral Sciences, vol. 15, pp. 4, 2015.

[3] The reference: "about $<$ the trans-pacific partnership agreement outline the bulletin>", http://iipdigital.usembassy.gov/st/chinese/texttrans/2011/11/20111115 174052x0.8178631.html\#axzz2xo3fb2Lk.

[4] Y.S. Hee, "A study on the intellectual property in the Trans Pacific Partnership Agreements", Journal of Industrial Property, vol. 43, pp. 123-153, 2014

[5] F. Neil, Intellectual property rights and the margins of international trade, Journal of international trade \& economic development, vol. 23, pp. 1-30, 2014.

[6] D.H. Gleeson, H. Moir, R. Lopert, "Costs to Australian taxpayers of pharmaceutical monopolies and proposals to extend them in the Trans-Pacific Partnership Agreement”, Medical journal of Australia, vol.202, pp.306-308, 2015. 